\title{
Cyclic Polarization Study of Thick Welded Joints of Lean Duplex Stainless Steel for Application in Biodiesel Industry
}

\author{
Dalila Chaves Sicupira ${ }^{a, c *}$, Ronaldo Cardoso Junior ${ }^{b}$, Alexandre Queiroz Bracarense ${ }^{b}$, Gerald S. \\ Frankel $^{\text {, Vanessa de Freitas Cunha Lins }}{ }^{a}$ \\ ${ }^{a}$ Chemical Engineering Department, Universidade Federal de Minas Gerais, Belo Horizonte, MG, \\ Brazil \\ ${ }^{b}$ Mechanical Engineering Department, Universidade Federal de Minas Gerais, Belo Horizonte, MG, \\ Brazil \\ ${ }^{c}$ Department of Materials Science and Engineering, Fontana Corrosion Center, The Ohio State \\ University, Columbus, OH, USA
}

Received: May 13, 2016; Revised: September 26, 2016; Accepted: November 21, 2016

\begin{abstract}
Thick welded joints of UNS S32304 lean duplex stainless steel (LDSS) has been studied in acidified glycerin, a byproduct of biodiesel plants, using cyclic polarization technique. LDSS S32304 thick plates were welded by different processes commonly employed in the fabrication process: shielded metal arc welding, gas metal arc welding and flux cored arc welding. The electrochemical behavior of different weldment zones was characterized. Transmission electron microscopy and scanning electron microscopy (SEM) were used for sample characterization. SEM images showed that the heat affected zone was the most critical zone for pitting corrosion for all samples. The results were associated to the microstructural features of the materials. Generally, the breakdown potential of the top regions of welds was higher in acidified glycerin than the weld root for welds fabricated with two different filler metals. Basically, all the welded samples exhibited similar or higher corrosion resistance, compared with the corresponding base metal.
\end{abstract}

Keywords: corrosion, duplex stainless steel, welding process, acidified glycerin

\section{Introduction}

Duplex stainless steels (DSSs) are materials that exhibit a combination of high yield strength, toughness and localized corrosion resistance, and they are being widely used in chemical, petrochemical, marine, nuclear and paper industry ${ }^{1}$. The best properties are obtained with approximately equal amount of austenite $(\gamma)$ and ferrite $(\alpha)$ phases $^{2}$.

Volatility of the Ni price has led to development of low alloy duplex steels ${ }^{3}$. The nickel content is partly replaced by manganese and nitrogen and also the molybdenum content is reduced in the so-called lean DSS (LDSS) ${ }^{4}$.

Exposure to high temperatures, for example during welding, can result in deterioration of DSS ${ }^{2-14}$. During welding, DSS undergoes microstructural changes that impact on their mechanical and corrosion properties, especially corrosion resistance and toughness ${ }^{2-14}$. The degradation comes from the unbalanced duplex phase fraction with excess of ferrite phase and the precipitation of deleterious secondary phases such as chromium nitrides, secondary austenite $\left(\gamma_{2}\right)$, sigma $(\sigma)$, chi $(\chi)$, etc. ${ }^{2-9}$. A great number of investigations have been carried out on welded DSS joint ${ }^{1-12}$. Although multipass welding is more common during fabrication, reports about multipass welding are scarce, especially for pipes of medium thickness or more.

* e-mail: dsicupira@ufmg.br
The localized corrosion of stainless steels is related to alloying elements as $\mathrm{Cr}$, Mo and $\mathrm{N}$, whereas Ni mainly acts to stabilize the austenite phase $\mathrm{e}^{13-15}$. A great number of investigations have studied the effect of alloying elements on corrosion resistance of stainless steels, especially N, which is most effective ${ }^{6,8,13,16,17}$. According to Hsieh et al.$^{18}$, a higher content of nitrogen and nickel favors the reformation of austenite. However, the effect of the nitrogen on the reformation of austenite is much greater than that of nickel. Hsieh et al. ${ }^{18}$ also showed that the effect of manganese on the formation of austenite can be negligible. Bhatt et al..$^{19}$ found that the presence of 5 and $10 \%$ nitrogen in the shielding gas, decreases the ferrite contents to 35 and $29 \%$, respectively, resulting in an improved pitting corrosion resistance of the weldments obtained by gas tungsten arc. According to Mesquita et al. ${ }^{15}$ the general corrosion resistance of Mo-containing DSS grades is increased. Mo has a stronger beneficial effect on the corrosion resistance of ferrite compared to austenite.

The pitting corrosion resistance of 2304 DSS welded by autogenous plasma-arc was evaluated by Tan et al. ${ }^{20}$. In this study, the as-welded samples showed impaired corrosion resistance and pitting preferentially occurred at ferrite grains in the heat affected zone (HAZ) near the fusion line. In another study in welded joints of 2304 DSS, Chen et al. ${ }^{8}$ found pits occurring in the ferrite phase for all simulated 
HAZ specimens and the corrosion resistance of welded joints is influenced by $\mathrm{Cr}_{2} \mathrm{~N}$ and inclusions. According to their results, the corrosion resistance of the HAZ in 2304 DSS decreased with the cooling rate.

Based on that, this study aims to evaluate the corrosion resistance of UNS S32304 LDSS thick plates welded by three different welding processes in acidified glycerin, a byproduct of biodiesel industry.

\section{Experimental Procedures}

\subsection{Materials}

Three different welding processes were used: shielded metal arc welding (SMAW), gas metal arc welding (GMAW) and flux cored arc welding (FCAW). For each welding process, two filler metals with different chemical compositions, $(23 \% \mathrm{Cr} 7 \% \mathrm{Ni})$ and $(22 \% \mathrm{Cr} 9 \% \mathrm{Ni} 3 \% \mathrm{Mo})$ were evaluated. The shielding gas for GMAW process was a ternary gas of $95 \% \mathrm{Ar}, 3 \% \mathrm{CO}_{2}$ and $2 \% \mathrm{~N}_{2}$, while for FCAW process a shielding gas with $75 \%$ Ar and $25 \% \mathrm{CO}_{2}$ was used. The same shielding gas flow rate of $18 \mathrm{~L} \cdot \mathrm{min}^{-1}$ was utilized for all welding processes.

The electrochemical behavior of different weldment zones (fusion zone (FZ), base metal (BM) and heat affected zone (HAZ)) was characterized in the top and root of the specimens. The chemical composition of the LDSS is shown in Table 1.

This work is a part of a global project to study the weldability of the UNS S32304 alloys ${ }^{21}$. The filler metals compositions, the welding parameters and the sample preparation for electrochemical tests were described by the authors in a previous work ${ }^{22}$.

\subsection{Microstructural characterization}

Microstructural examination of specimens was conducted using an optical microscope (Olympus PME 3, LECO). After polishing, the specimens were then electrolytically etched in $10 \%$ oxalic acid electrolyte at $6 \mathrm{~V}$ for $60 \mathrm{~s}$. A Tecnai G2-20 - SuperTwin FEI - 200kV transmission electron microscope (TEM) was used for identification of the precipitates in LDSS. After the polarization tests, microstructural observations were carried out using scanning electron microscopy (SEM, Quanta 200F, FEI).

\subsection{Electrochemical measurements}

The tests were performed at a temperature of $65 \pm 1^{\circ} \mathrm{C}$ and under constant stirring to simulate the operational conditions in the pipes of biodiesel plants. A conventional three-electrode cell was used, the working electrodes being prepared from the LDSS welded samples with an exposed surface of approximately $1 \mathrm{~cm}^{2}$. The reference was a saturated calomel electrode (SCE) and a Pt mesh was used as the counter electrode.

Cyclic potentiodynamic polarization tests were performed in an industrial acidified glycerin provided by a biodiesel plant with 49.5 wt. $\%$ glycerin, 29 wt. $\%$ methanol, 17 wt. $\%$ water, 3 wt. $\% \mathrm{NaCl}$, and $1.5 \mathrm{wt} . \%$ organic materials, $\mathrm{pH}=6.2$ and conductivity of $4.9 \mathrm{mS} / \mathrm{cm}$. An Ivium compactstat potentiostat was used to measure the open circuit potential (OCP) for 1 $\mathrm{h}$ and the cyclic potentiodynamic polarization curves were then measured at a scan rate $0.167 \mathrm{mV} / \mathrm{s}$ from the open circuit potential (OCP) until the current density reached $5 \mathrm{~mA} . \mathrm{cm}^{-2}$ at which point the scanning direction was then reversed. Three replicate tests of each measurement were performed.

\section{Results and discussion}

\subsection{Microstructure}

Similarly to previous investigations ${ }^{22}$, the fusion zone (FZ) structure consists of austenite grains in the form of Widmanstätten plate precipitates and secondary austenite $\left(\gamma_{2}\right)$ within a matrix of ferrite, and also, FZ region showed higher proportions of austenite than HAZ. The presence of secondary austenite $\left(\gamma_{2}\right)$ can be verified in FZ, as detailed in Figure 1.

It is noteworthy that this type of austenite formed in the temperature range $800-1000^{\circ} \mathrm{C}$ and it is derived by dissolving $\mathrm{Cr}_{2} \mathrm{~N}$ precipitates, which provides nitrogen to the formation of $\gamma_{2}$ ${ }^{23}$, and its nucleation originates in inclusions and dislocations ${ }^{23}$. The HAZ exhibited chromium nitrides mainly in the interior of the ferrite grains. Nitride precipitation is more likely to occur in the ferrite phase because the solubility of nitrogen in ferrite drops rapidly with the decrease in temperature. Figure 2 shows the weld profile of the sample (BM, HAZ and FZ) and the nitride colonies within the ferrite grains in the HAZ of UNS S32304.

Transmission electron microscopy indicated the presence of precipitates in the welded specimens as shown in Figure 3. Comparison with the results of other studies indicates that the precipitates are $\mathrm{Cr}_{2} \mathrm{~N}^{24}$.

Figure $3 \mathrm{a}$ and $3 \mathrm{~b}$ shows the results of the TEM analysis of the $\mathrm{Cr}_{2} \mathrm{~N}$ formed in the $\mathrm{HAZ}$ of as-welded sample. Figure $3 \mathrm{a}$ indicates that all precipitates observed in the HAZ are rod-like $\mathrm{Cr}_{2} \mathrm{~N}$ precipitated intragranularly. In addition to the intragranular rod-like nitrides, some $\mathrm{Cr}_{2} \mathrm{~N}$ particles are also observed along the ferrite/austenite interfaces (Figure $3 \mathrm{~b}$ ).

Table 1: Chemical composition of the base metal

\begin{tabular}{lccccccccccc}
\hline Element & $\mathrm{C}$ & $\mathrm{Mn}$ & $\mathrm{Si}$ & $\mathrm{P}$ & $\mathrm{S}$ & $\mathrm{Cr}$ & $\mathrm{Ni}$ & $\mathrm{Mo}$ & $\mathrm{Cu}$ & $\mathrm{N}$ & $\mathrm{O}$ \\
\hline $\begin{array}{l}\text { Content } \\
(\% \mathrm{wt})\end{array}$ & 0.019 & 1.35 & 0.39 & 0.0282 & 0.00040 & 22.45 & 3.63 & 0.44 & 0.50 & 0.1128 & 0.0033 \\
\hline
\end{tabular}




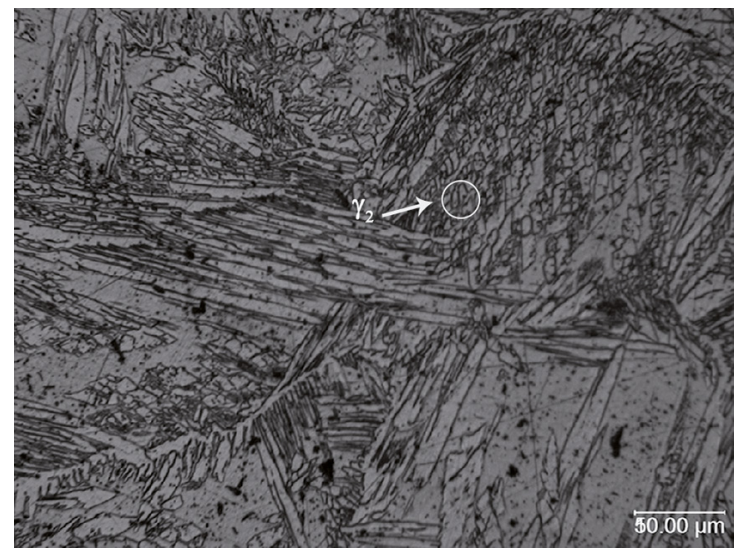

Figure 1: OM micrograph of secondary austenite in the FZ (FCAW root of weld joint with 2209 as filler metal)

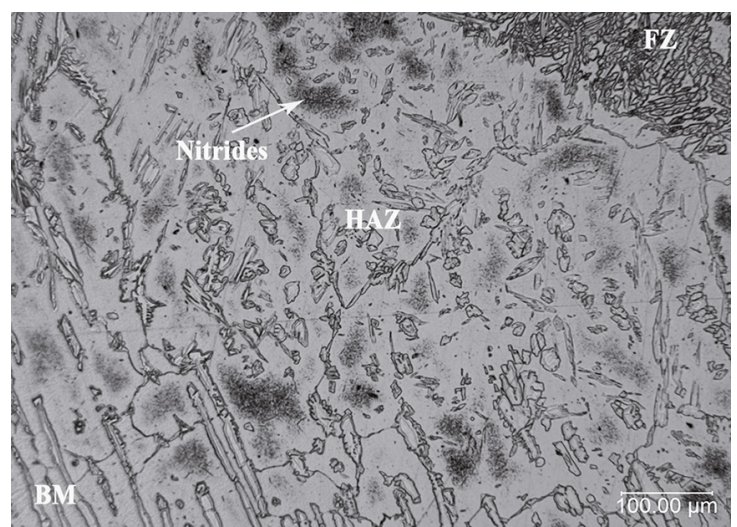

Figure 2: OM micrograph of nitride colonies in the interior of a ferrite grain in the HAZ of UNS S32304 (FCAW top of weld joint with 2209 as filler metal)

\subsection{Electrochemical behavior}

Figure 4(a-c) shows typical cyclic potentiodynamic polarization curves obtained for samples welded using SMAW, GMAW and FCAW processes, respectively. The
OCP values and breakdown potentials $\left(\mathrm{E}_{\mathrm{b}}\right)$ from polarization tests are summarized in Figure 5.

The welded joints exhibited higher values of corrosion potential than the lean duplex steel in the as received condition, except for the root region of joint welded using SMAW process and 2307 consumable, which showed the lowest corrosion and breakdown potentials among the studied samples, which can be related with the lowest heat input used in the welding process in the case of SMAW 2307 root region, as showed in a previous work ${ }^{22}$. The highest breakdown potential was identified for the top region of the lean duplex joint welded using SMAW process and 2209 consumable, which can be related with the highest heat input used for this sample. This difference in the heat input was described by Cardoso Junior et al. ${ }^{21}$ as being an experimental deviation occurred during the manual SMAW welding process. In general, top regions showed higher values of $E_{b}$ than root samples, due to higher filler metal dilution for root regions. The filler metals used (2307 and 2209) have higher Ni content than the base metal and presence of Mo in the case of 2209. Nickel stabilizes austenite, while molybdenum stabilizes ferrite and contributes to increase PREN of ferrite. Tan et al. ${ }^{25}$ reported that the pitting corrosion resistance of a super duplex stainless steel was determined by the pitting resistance equivalent number of weaker phase. If the PREN of the weaker phase increases, the global corrosion resistance of steel increases. The content of $\mathrm{Ni}$ and Mo extends the passive region and strengthens the passive layers of the samples ${ }^{26}$. Considering the standard deviation, no remarkable difference between the welding processes was observed (Figure 5).

As the potential increased, a sharp rise in current density was seen, suggesting the occurrence of pitting corrosion. Wide passive regions were observed for all samples tested and the pitting potentials were all $200-400 \mathrm{mV}$ higher than the corresponding open circuit potentials. These observations indicate that the samples have excellent resistance to the initiation of pitting corrosion in this chloride environment. In general,
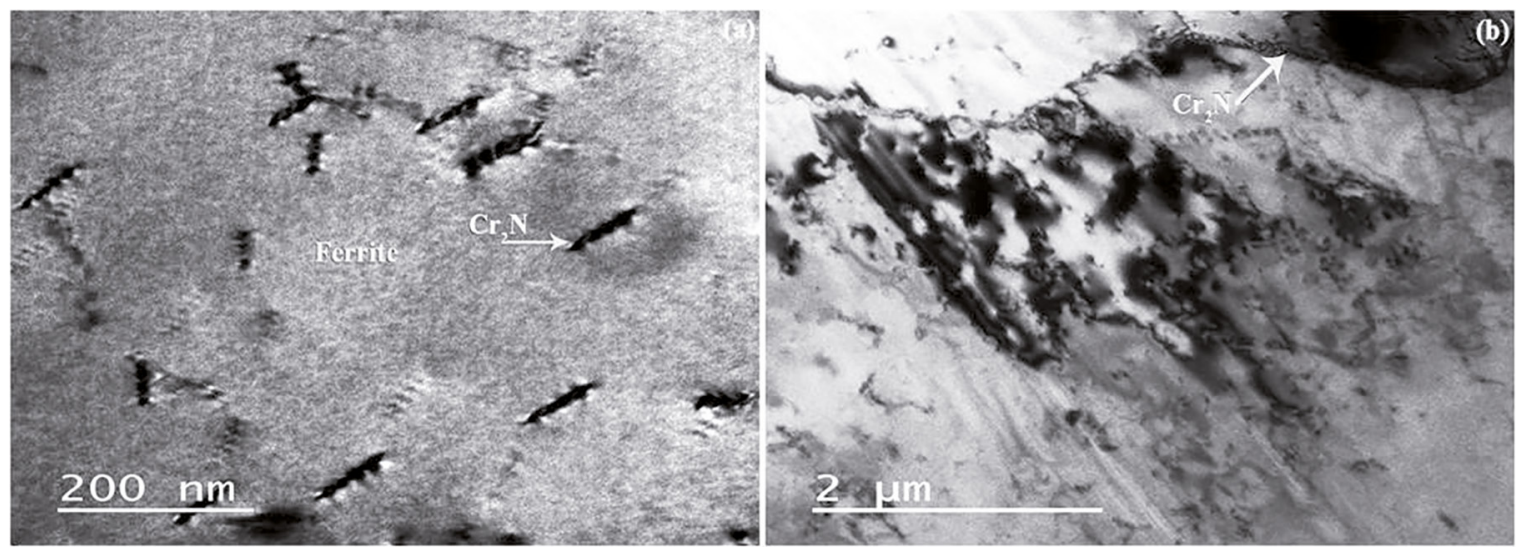

Figure 3: Transmission electron micrograph of $\mathrm{Cr} 2 \mathrm{~N}$ of the $\mathrm{HAZ}$ of welded joints. (a) Transmission electron micrograph of the intragranular nitrides and (b) transmission electron micrograph of the nitrides precipitated at the ferrite/austenite interfaces (FCAW top region and 2307 as filler metal) 

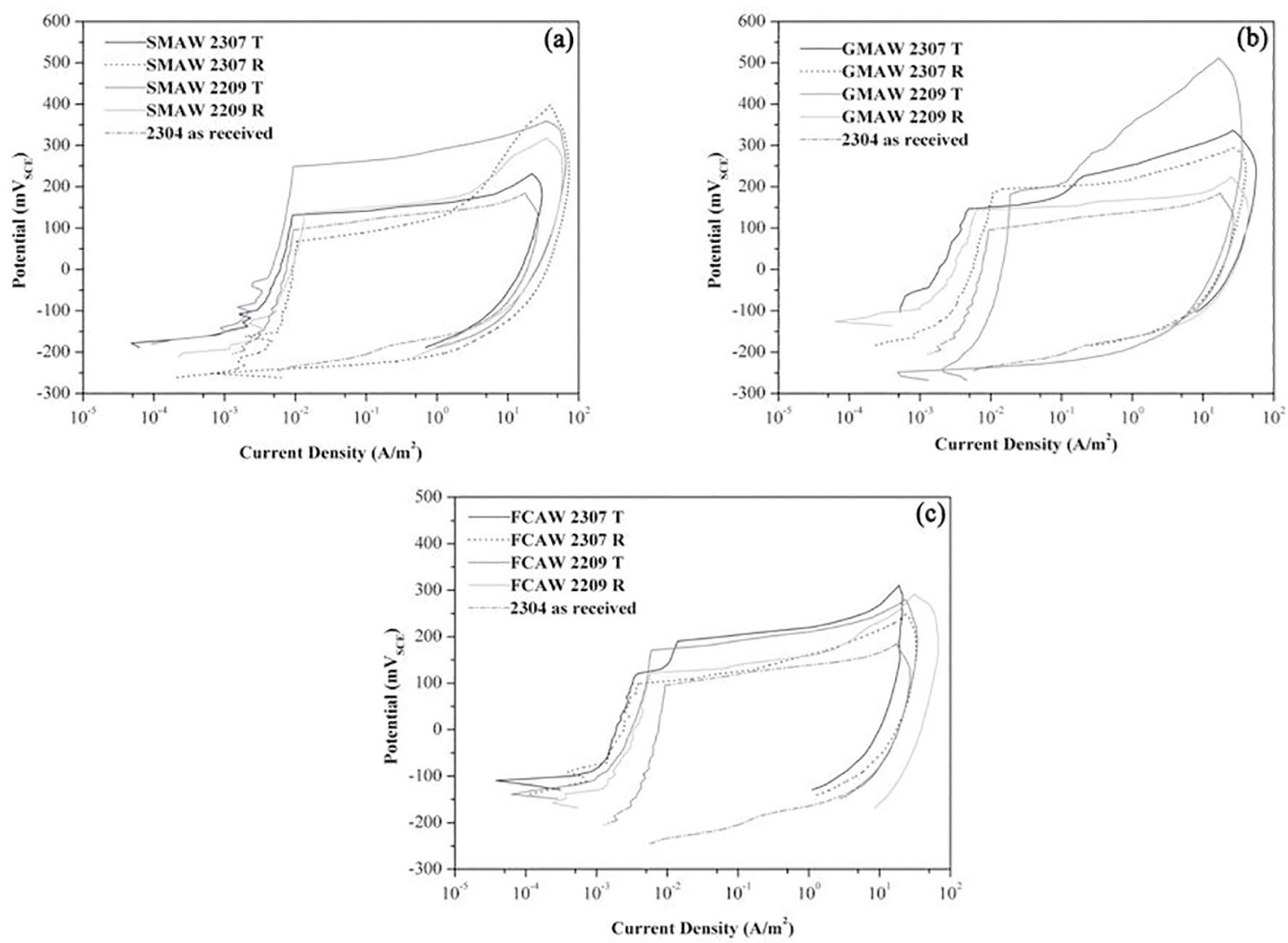

Figure 4: Cyclic potentiodynamic polarization curves for (a) SMAW (b) GMAW and (c) FCAW process. T - top of weld, R - root of weld

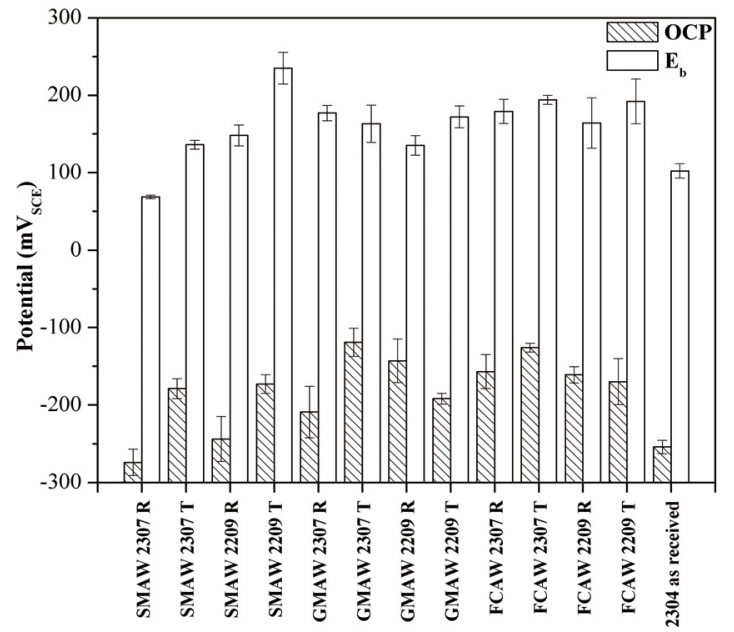

Figure 5: Experimental data for cyclic polarization tests. T - top of weld, $\mathrm{R}$ - root of weld

no remarkable decrease in pitting potential was found after the welding. The repassivation potentials during the reverse scans were also similar. The backward polarization (Figure 4) showed a positive hysteresis, a large hysteresis loop and low repassivation potential, similar in value to the OCPs, which indicate that pitting corrosion might occur over long periods of open circuit exposure to the acidified glycerin solution, which contained $3 \% \mathrm{NaCl}$. According to Marcus et al. ${ }^{27}$, after depassivation, the repassivation can be hindered by chloride adsorbed on the metal surface resulting in formation of nanopits.

For a more detailed understanding of the pitting corrosion of the joints, the samples were observed using SEM analysis after the cyclic potentiodynamic testing. An example is shown in Figure 6.

As shown by the authors in a previous work ${ }^{22}$, the $\mathrm{FZ}$ was more resistant than the HAZ and the pits, in all of welded joints, occurred mostly in the HAZ (Figure 6). The sites for nucleation of pits were probably chromium nitride particles, as suggested by Tan et al. ${ }^{20}$. All of the HAZ regions exhibited more pits than the other regions and the HAZ was always the most susceptible zone. Some pits were found to initiate in the vicinity of inclusions in either the $\delta$ or $\gamma$ phase. Others were formed at the $\delta / \gamma$ interface or within the $\delta$ phase.

The higher susceptibility of the HAZ to pitting corrosion was found for all welded joints, and it resulted from two aspects of the microstructure evolution during welding. The $\mathrm{Cr}$ and Mo contents are diluted by an increase in the $\delta$ volume fraction, so $\mathrm{Cr}$ and $\mathrm{Mo}$ content of ferrite phase in the HAZ is lower than in the parent metal and, also, $\mathrm{Cr}_{2} \mathrm{~N}$ precipitated in the ferrite phase due to the lower solubility of nitrogen in ferrite ${ }^{6,8,9,14,20,23,28-32}$. According to Hsieh et al. ${ }^{18}$ the reformation of austenite in HAZ is limited with 

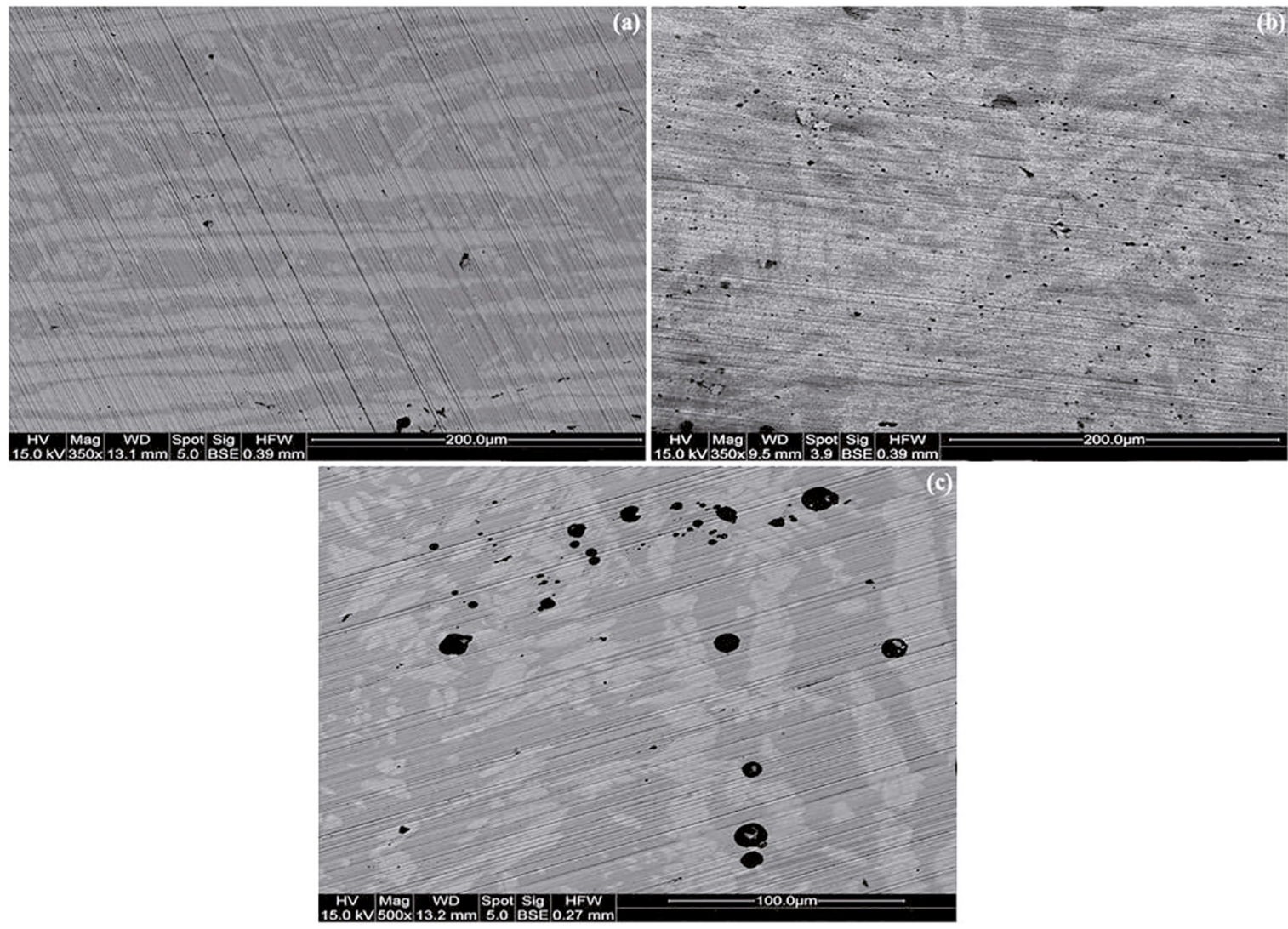

Figure 6: Pit morphologies after polarization measurements (SMAW 2307 top region): (a) BM (b) FZ and (c) HAZ

nitrogen and nickel contents lower than 0.15 and $5.5 \%$ (as the studied UNS S32304), respectively, even in the cases of increased cooling time ${ }^{18}$. According to Hsieh et al. ${ }^{18}$ the austenite content in the HAZ cannot fall below $25 \%$ in order to avoid precipitation of $\mathrm{Cr}_{2} \mathrm{~N}$ and guarantee superior pitting corrosion resistance at the HAZ. The pits showed in Figure 6 were believed to be related to the $\mathrm{Cr}_{2} \mathrm{~N}$ precipitates. These precipitates resulted in depletion in $\mathrm{Cr}$ in the adjacent matrix region. The chromium-depleted zones provide a favorable site for pitting corrosion nucleation, as reported by several authors $6,8,9,14,20,23,28-32$.

According to Marcus et al. ${ }^{27}$, the presence of microstructural defects on the samples such as metal grain boundaries or interfaces between the matrix and inclusions or second phase particles can promote local breakdown. In this work the breakdown has, preferentially, occurred at surface defect sites such as non-metallic inclusions or precipitates.

\section{Conclusions}

The corrosion behavior of joints of lean duplex stainless steel, UNS S32304, welded by three different processes, was studied. The following was observed:

- All welded samples exhibited similar or higher corrosion resistance, compared with the corresponding base metal.
- The pitting corrosion resistance of the whole joint has improved compared to as received samples, as a consequence of alloying elements enhanced in ferrite and austenite.

- Considerable precipitation of chromium nitrides was observed at grain boundaries or ferrite grains on the as-welded specimens.

- Some pits were found to initiate in the vicinity of inclusions and others were formed at the interface $\delta / \gamma$ or within $\delta$ phase.

- The pits in HAZ are believed to be related to the $\mathrm{Cr}_{2} \mathrm{~N}$ precipitates.

\section{Acknowledgements}

This work was financially supported by CAPES, CNPq and FAPEMIG.

\section{References}

1. Asif M M, Shrikrishna KA, Sathiya P, Goel S. The impact of heat input on the strength, toughness, microhardness, microstructure and corrosion aspects of friction welded duplex stainless steel joints. Journal of Manufacturing Processes. 2015;18:92-106. 
2. Garzón CM, Ramirez AJ. Growth kinetics of secondary austenite in the welding microstructure of a UNS S32304 duplex stainless steel. Acta Materialia. 2006;54(12):3321-3331.

3. Alvarez SM, Bautista A, Velasco F. Corrosion behaviour of corrugated lean duplex stainless steels in simulated concrete pore solutions. Corrosion Science. 2011;53(3):1748-1755.

4. Westin EM, Olsson COA, Hertzman S. Weld oxide formation on lean duplex stainless steel. Corrosion Science. 2008;50(9):2620-2634.

5. Westin E. Microstructure and properties of welds in the lean duplex stainless steel LDX2101 ${ }^{\circledR}$. [Doctoral Thesis]. Stockholm: School of Industrial Engineering and Management, Royal Institute of Technology; 2010.

6. Tan H, Wang Z, Jiang Y, Yang Y, Deng B, Song H, et al. Influence of welding thermal cycles on microstructure and pitting corrosion resistance of 2304 duplex stainless steels. Corrosion Science. 2012;55:368-377.

7. Pilhagen J, Sandström R. Influence of nickel on the toughness of lean duplex stainless steel welds. Materials Science and Engineering: A. 2014;602:49-57.

8. Chen L, Tan H, Wang Z, Li J, Jiang Y. Influence of cooling rate on microstructure evolution and pitting corrosion resistance in the simulated heat-affected zone of 2304 duplex stainless steels. Corrosion Science. 2012;58:168-174.

9. Jiang Y, Tan H, Wang Z, Hong J, Jiang L, Li J. Influence of $\mathrm{Cr}_{\text {eq }}$ ' $\mathrm{Ni}_{\text {eq }}$ on pitting corrosion resistance and mechanical properties of UNS S32304 duplex stainless steel welded joints. Corrosion Science. 2013;70:252-259.

10. Nowacki J, Łukojć A. Structure and properties of the heat-affected zone of duplex steels welded joints. Journal of Materials Processing Technology. 2005;164-165:1074-1081.

11. Kang DH, Lee HW. Study of the correlation between pitting corrosion and the component ratio of the dual phase in duplex stainless steel welds. Corrosion Science. 2013;74:396-407.

12. Souza CS, Lins VFC, Silveira DM, Costa CGF, Cardoso Junior R, Campos FR, et al. Avaliação da soldagem multipasse de chapas espessas de aços inoxidáveis lean duplex UNS S32304 soldadas pelos processos SMAW, GMAW e FCAW - Parte II: resistência à corrosão. Soldagem e Inspeção. 2012;18(3):257-267.

13. Weber L, Uggowitzer PJ. Partitioning of chromium and molybdenum in super duplex stainless steels with respect to nitrogen and nickel content. Materials Science and Engineering: A. 1998;242(1-2):222-229.

14. Ha HY, Jang MH, Lee TH, Moon J. Interpretation of the relation between ferrite fraction and pitting corrosion resistance of commercial 2205 duplex stainless steel. Corrosion Science. 2014;89:154-162.

15. Mesquita TJ, Chauveau E, Mantel M, Kinsman N, Roche V, Nogueira RP. Lean duplex stainless steels-The role of molybdenum in pitting corrosion of concrete reinforcement studied with industrial and laboratory castings. Materials Chemistry and Physics. 2012;132(2-3):967-972.

16. Ramirez AJ, Brandi SD, Lippold JC. Secondary austenite and chromium nitride precipitation in simulated heat affected zones of duplex stainless steels. Science and Technology of Welding and Joining. 2004;9(4):301-313.
17. Garzón CM, Serna CA, Brandi SD, Ramirez AJ. The relationship between atomic partitioning and corrosion resistance in the weldheat affected zone microstructures of UNS S32304 duplex stainless steel. Journal of Materials Science. 2007;42(21):9021-9029.

18. Hsieh RI, Liou HY, Pan YT. Effects of cooling time and alloying elements on the microstructure of the gleeble-simulated heataffected zone of $22 \% \mathrm{Cr}$ duplex stainless steels. Journal of Materials Engineering and Performance. 2001;10(5):526-536.

19. Bhatt RB, Kamat HS, Ghosal SK, De PK. Influence of nitrogen in the shielding gas on corrosion resistance of duplex stainless steel welds. Journal of Materials Engineering and Performance. 1999;8(5):591-597.

20. Tan H, Wang Z, Jiang Y, Han D, Hong J, Chen L, et al. Annealing temperature effect on the pitting corrosion resistance of plasma arc welded joints of duplex stainless steel UNS S32304 in 1.0M $\mathrm{NaCl}$. Corrosion Science. 2011;53(6):2191-2200.

21. Cardoso Junior R, Bracarense AQ, Campos FR, Souza CS, Silveira DM, Lins VFC. Avaliação da soldagem multipasse de chapas espessas de aços inoxidáveis lean duplex UNS S32304 soldadas pelos processos SMAW, GMAW e FCAW - Parte 1: propriedades mecânicas. Soldagem e Inspeção. 2012;17(4):306-316.

22. Sicupira DC, Frankel GS, Lins VFC. Pitting corrosion of welds in UNS S32304 lean duplex stainless steel. Materials and Corrosion. 2016;67(5):440-448.

23. Ramirez AJ, Lippold JC, Brandi SD. The relationship between chromium nitride and secondary austenite precipitation in duplex stainless steels. Metallurgical and Materials Transactions A. 2003;34(8):1575-1597.

24. Yang Y, Yan B, Li J, Wang J. The effect of large heat input on the microstructure and corrosion behaviour of simulated heat affected zone in 2205 duplex stainless steel. Corrosion Science. 2011;53(11):3756-3763.

25. Tan H, Jiang Y, Deng B, Sun T, Xu J, Li J. Effect of annealing temperature on the pitting corrosion resistance of super duplex stainless steel UNS S32750. Materials Characterization. 2009;60(9):1049-1054.

26. Blasco-Tamarit E, Igual-Munõz A, Anton JG, García-García D. Effect of aqueous $\mathrm{LiBr}$ solutions on the corrosion resistance and galvanic corrosion of an austenitic stainless steel in its welded and non-welded condition. Corrosion Science. 2006;48(4):863-886.

27. Marcus P, Maurice V, Strehblow HH. Localized corrosion (pitting): A model of passivity breakdown including the role of the oxide layer nanostructure. Corrosion Science. 2008;50(9):2698-2704.

28. Liou HY, Hsieh RI, Tsai WT. Microstructure and pitting corrosion in simulated heat-affected zones of duplex stainless steels. Materials Chemistry and Physics. 2002;74(1):33-42.

29. Chehuan T, Dreilich V, Assis KS, Sousa FVV, Mattos OR. Influence of multipass pulsed gas metal arc welding on corrosion behaviour of a duplex stainless steel. Corrosion Science. 2014;86:268-274.

30. Bettini E, Kivisäkk U, Leygraf C, Pan J. Study of corrosion behavior of a $22 \% \mathrm{Cr}$ duplex stainless steel: Influence of nano-sized chromium nitrides and exposure temperature. Electrochimica Acta. 2013;113:280-289. 
31. Zhang Z, Wang Z, Jiang Y, Tan H, Han D, Guo Y, et al. Effect of post-weld heat treatment on microstructure evolution and pitting corrosion behavior of UNS S31803 duplex stainless steel welds. Corrosion Science. 2012;62:42-50.
32. Zhang Z, Zhao H, Zhang H, Yu Z, Hu J, He L, et al. Effect of isothermal aging on the pitting corrosion resistance of UNS S82441 duplex stainless steel based on electrochemical detection. Corrosion Science. 2015;93:120-125. 